いつもとのような值が出るとは限らない。これらの無水 硫酸カルシウムは水和性をるつているが，乙かし水中に 放置したのみではなかなか結晶となりにくいるのでめ る。われわ秃は工業的に如何にして迅速にそして多量に 結晶石育を製造しうるかについて研究を進めた。即ら無 水硫酸カルシウムはいろいろの酸, 塩特にアルカリ㙉と 作用して結晶石膏に容易に化成出来ることは知られてい るけれ共，これを定量的比㘹的に行ら方法はな されなかつたのである。これについては

（1）結晶化速度を進める促進溶液の発見（種類，濃度 等)

（2）原料の処理（水七，粉碎，及び仕込条件）

(3) 攪拌の条件

の三つの点から結晶の純化と結晶化速度の増大を追求 し，大体に拓いて所期の成果を得た。現在東芝川口工場 で試作を開始中でめるが現在までに工場で得られたるの の中で結合給水の最高のものは次の通りでむる。

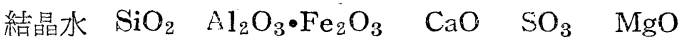
$20.25 \%$ -
$0.6 \%$
$31.99 \%$ 46. $84 \% \quad 0.14 \%$

これらの結晶は板状若しくは板状に近い桂状でめる。

混水量政化膨脤耐压

A $25 \% \quad 0.17 \%$

i) $50 \%$

-
結晶石高への転化時間は大体 2 日でめつた。この反店 終了後の溶液はくり返し使用出来るのであるのがこの方 法の利点と言えるのでめつて，溶夜の濃度を正確にして 顿けげ良質の結晶は連続的に製造出来るのでめる。勿論 夏期の場合は幾分反応時間は長くなるけれ共，大体比打 いて 2 日で結晶化は終る。な打最近で红更に短時間で結 晶化の出来ることが判つた。

次にてれらの焼石膏を a) 平鉒，b) 加圧釜の二つに

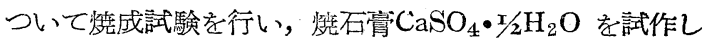
た。その結果は次の通りでめる。

1. 平釡によるもの (某社測定)

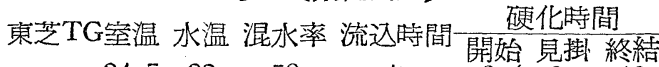

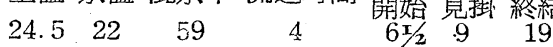

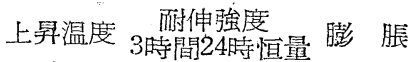

$21.5246 \quad 373 \quad 1.26$

な颃拊圧強度はわれわれの測定では3時間 $97 \mathrm{~kg} / \mathrm{cm}^{2}$, 空中放置48時間後のbのは3時間 $277.8 \mathrm{~kg} / \mathrm{cm}^{2}$ の強度が 得られている。

2. 加压釜による場合，条件として $130^{\circ} \mathrm{C} 191 \mathrm{bs}$ 附近厄 蝰成した。反応時間は約 5 時間であつた。

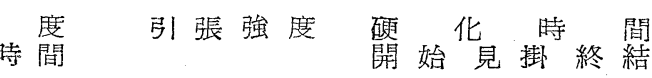
6分 15 分 30 分

焼石膏については木だ充分破究していないので発表は 出来ない点が多いけれども，現在なで得られた最高の 值として耐压強度 3 時間で $230 \mathrm{~kg} / \mathrm{cm}^{2}$ ，耐伸強度 3 時間 $24 \mathrm{~kg} / \mathrm{cm}^{2}$ である。な特遲速郕を入れることによりいる いろと条件を变へることが出来る。

これらの焼石督が果して単味で使用できるかどらかに ついて実際に試験を行い（1）ギプス用，（2）石膏像
$3.0 \mathrm{~kg} / \mathrm{cm}^{2}$

$100 \mathrm{~kg} / \mathrm{cm}^{2}$
$22.16 \mathrm{~kg} / \mathrm{cm}^{2}$

用，(3) 歯科用，(4) 型材用等厄ついて出 (4) 以 外については完全に応用することが出来た。な括（4） についても硬化時間, 硬化膨脹の速度を加減することに 成功しつつ多るので近く好結果が得られると思示れる。 な抢この研究化りいては東大の永井彰一郎先生の御熱 心な御助言に感謝する。

\title{
XVII. ドロマイトクリンかに關するニ三の研究結果
}

磐城セメント株式会社、直田義彰・○宫澤 清

ドロマイトクリンカをロータリキルンで焚成するに 峙，セメントクリシカの場合と買なり，1600 $\mathrm{C}$ 以上の高 温が必要でめる。そのため煉瓦の選択とその煉瓦に対す るコーチングの附著如何が燷瓦の耐久性に重大な影響を 及将すると考えられる。ロータリキルンでドロマイト クリンカを焼成した場合の煉瓦コーチングについては本 年のセメント製造技術交流懇談会で当社吉田，佐藤両氏 が発表したが，とれについて詳細調べたので，その結 果とドロマイトクリンカを炉材として電気炉操業に実際
に使用した場合の爐床の侵触状態等について研究した結 果の二三を報告する。

ドロマイトクリンカを製造する場合，粉砕した微粉調 合原料をろークとして䑁成する方法を微粉法，ドロマイ

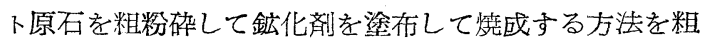
粒法と便宜上名づけると, 燤瓦コーチングは微粉法, 粗 粒法いずれの場合も㷧とんど同様なものが生成せらる。 即ら，煉瓦表面にスピネルを主体とするものが生成し， その上に黄褐色の愹融層が生成し, 更にその上にカルシ 
ウムシリケートの薄層を生成し，一番外側にクリンカコ 一チングが附著する。これらの各層について化学分析， 顕微鏡観察及びX線試験を行つた。 その結果

（1）黄色熔融層は遊離石灰が浮とんぞ無く，40〜50 \%の遊離苦土が存在し，他にダネシウムシリケー ト，カルシウムシリケート，スピネル等の化合物を 含む㥞である。

(2) スピネル層は邀離苦士が法とんぞ無く，主とし て $\mathrm{MgO} ・ \mathrm{Al}_{2} \mathrm{O}_{3}$ より成り,他に少量のシリケート, ア ルミネート等を含导様でする。

（3）上記二層恃消化性に強く数ケ月を経過するも全
然異状を詔めない。

更にドロマイトクリンカと焼ドロマイトをno binder で筑爐した場合の電気爐床の侵蝕状態を示す試料を大手 したので，との試料について化学分析と顕微鏡試験を行 つた。

\section{その結果}

侵蝕部ではシリろートとペリクレーズが生成しっぺリ クレーズは黄褐一黑褐に呈色し, 各粒は分離して非常に 大きく成長して括り，クリンカと焼ドロマイトの組織俚 侵蝕のために崩潰するが，ペリクレーズはそのま離脱 しつつ岁るととが明が認められた。

\section{XVIII. トロマイトクリンカの消化機等（第1 報）}

ドロマイトクリンカを空気中で䝪藏する場合の消化崩 潰の原因仗，未反応の $\mathrm{CaO} の$ 水和が主体をなし，更に結 晶発育の悪いペリクレーズも激しい水和反応て膨脹亀裂 を起すことは周知の通りでめり，耐消化性を增すために 種及の鉱化剤を加穴て石灰を安定化することが行われて いる。しかしながら，岁る限られた量の釷化剤を添加す るのみであるから，クリンカ中つ遊離石灰を安定化合物 に固定するととは困難であるととは当然であり， $\mathrm{CaO}$, $\mathrm{MgO}$ の大部は遊離状態に残存している。クリンカの耐 消化性を改善するためには，まづクリンカの消化機構を 解明するととが必要で为り, 同時にクリンカの組織を研 究するととが重要となる。從来ドロマイトクリンカの研 究を行つた人達は多いが，ほとんどクリンカの構造につ いて報告されていない。著者は消化機棈を研究するため に，ずクリンカの粉碎物について種々の条件で消化せ しめ，消化物について化学分新，熱天科による生成物の

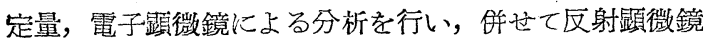
によりクリンカ組織の研究を行つた。

試料はロータリキルンで工業的敒製造されたドロマイ
整城セメント株式会社直田義彰・○営澤，淸

トクリンカを粉砕して使用した。 その結果

(1)試粼のX線試験の結果主として遊離石灰, ペリ クレーズより成るととを認めた。

（2）試料を空気中で風化せしめた場合は $\mathrm{CaO} \rightarrow$ $\mathrm{Ca}(\mathrm{OH})_{2} \rightarrow \mathrm{CaCO}_{3}$ の変化が起り, 大部分の $\mathrm{CaO}$ 60 日後では $\mathrm{CaCO}_{3}$ に变化したが, $\mathrm{MgO}$ の水和は僅少 である。それ故塊を貯藏した場合には燒結度の極く 悪いクリンカを除いては風化作用㣖Free $\mathrm{CaO}$ の水

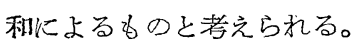

（3）試料をオートクレーブで加圧処理をしても苦士 の水和は完全でない。

更にクリンカの研磨面を空気中に放置し反射顕微鏡で 観察した結果, 新鮮クリンカの研酭面ではペリクレーズ 粒のみが観察されるが，筀気中に放置すると遊離石灰が 水和し始めetchingした時の㥞な状態となり, 石厄の部分 は黑色に磨蝕されて現れ，次第に円多を帯び，二三日を 経過するとフェライト，アルミネート等の部分を除いて は視野が朦酸となり白粉化してくる。

\section{XIX，海水マグネシアによるマグネシアセメント（第 2 報）}

\section{東京大学工学部応用化学科永并彰一郎・ $\bigcirc$ 福森 康}

第 1 報で報告したのは苦汼から消石灰又は生石灰を使 用して得た水酸化マグネシウムを水洗乾燥したものにつ いて, 600 900 90 各温度に焼成したいわゆる海水マグ ネシアをボーメ22, 25,28度の苦汁液で混練, 硬化させた マグネシアセメントについて比較試験した結果について
䌆めたものでめる。この結果から，海水マグネシアには その製法の如何によつて石灰分が少くても5\%位，多い のは8〜10\%,時には15\%にも及ぶものがあつて，ての海 水マグネシアを塩基性耐火物のマグネシア熯瓦，マグネ シアクリンカー，フオルステライト質のマグナイト，ク 